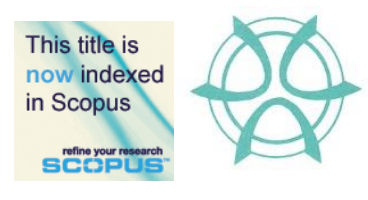

PLANNING MALAYSIA:

Journal of the Malaysian Institute of Planners

VOLUME 17 ISSUE 2 (2019), Page 38 - 49

\title{
URBANISATION BEYOND ITS CORE BOUNDARY AND ITS IMPACT ON THE COMMUNITIES IN GEORGE TOWN CONURBATION, MALAYSIA
}

\author{
Narimah Samat ${ }^{1}$, Mohd Amirul Mahamud ${ }^{2}$, Siti Masayu Rosliah Abdul \\ Rashid $^{3}$, Yasin Elhadary ${ }^{4}, \&$ Norzailawati Mohd Noor ${ }^{5}$ \\ ${ }^{1,2,3}$ School of Humanities \\ UNIVERSITI SAINS MALAYSIA \\ ${ }^{4}$ Department of Geography and Environment \\ UNIVERSITY OF KHARTOUM SUDAN \\ ${ }^{5}$ Kulliyyah of Architecture and Environmental Design \\ INTERNATIONAL ISLAMIC UNIVERSITY MALAYSIA
}

\begin{abstract}
Rapid urbanisation has raised major issues, especially in cities in developing nations. In Malaysia, for example, the urbanisation rate is at $74 \%$, but the size of urban land is less than $10 \%$. This phenomenon has caused urban expansion to encroach on to its fringe areas. At present, although much has been said about the economic benefits of urban expansion to the fringe areas, yet little is known about its impact on the local communities. This paper aims to highlight the spatial expansion of George Town Conurbation and to investigate how local inhabitants perceive urban development. This study used satellite images and GIS techniques to identify the spatial expansion of urbanisation in George Town. Quantitative and qualitative approaches of data collection were employed to investigate the impact of urbanisation on the communities. The findings indicated that the inhabitants in less urbanized states welcome urban expansion, as they perceive that urban growth generates more jobs and brings economic opportunities. On the contrary, those who have experienced a longer period of urban development did not fully welcome urbanisation. Therefore, inclusive development policies are required to ensure that urban growth will benefit dwellers in the urban area as well as in its surroundings. In addition, they are required to safeguard the environment.
\end{abstract}

Keywords: conurbation, GIS, land use changes, urban economy, urbanisation, Malaysia 
PLANNING MALAYSIA

Journal of the Malaysia Institute of Planners (2019)

\section{INTRODUCTION}

Urban areas worldwide are experiencing rapid urbanisation. In 1950, the urban population was less than one billion. Meanwhile, in 2009 it has increased to 3.4 billion, and is estimated to reach 5.0 billion and 6.4 billion in 2030 and 2050, respectively (United Nations, 2014). According to Knieling (2014), the global urban population is anticipated to increase by $1.5 \%$ per year, that is, increasing roughly at 60 million per year between 2025 and 2030. These figures reflect not only an increase in urban citizens, but also a shift in the relative share of people living in urban versus rural areas. The share of the urban population grew from just about $30 \%$ in 1950 to $54.4 \%$ in 2016 (UN-Habitat, 2016). Knieling predicted that this growth rate is expected to reach $70 \%$ by 2050 . Knieling also commented that this extraordinary increase has led some scholars to name this century as "urban age". More important is that urbanisation is growing more rapidly in developing countries than in developed nations (Jedwab \& Vollrath, 2015; McGee, 2009), with 95\% of urban expansion in the next decades will be occurring in the developing countries (UN-Habitat, 2016). It would be a huge challenge for planners and urban managers to ensure that urbanisation and urban spatial expansion will bring positive economic and developmental impact on the communities, and to safeguard the environment (Elhadary, Samat, \& Franklin, 2013).

Presently, however, the new trend of urban development in developing countries is no more confined to the formal administrative borders of core cities; the urban population is pushing towards urban fringe areas of neighbouring communities (McGee, 2009; Samat, Ghazali, Hasni, \& Elhadary, 2014). This phenomenon can be explained by using the concept of conurbation and agglomeration, as suggested by McGee (2009) when two spatial processes will dominate the growth of urban places. First, the growth of central cities in megaurban regions, and second an ongoing process of horizontal urban expansion into surrounding hinterlands creating peri-urban regions that will comprise up to $70 \%$ of mega-urban region population by 2050 . In the era of the "urban age" the number of rapidly growing megacities or megaregions with population of 10 to 20 million people have emerged primarily in Africa, America and Asia (Knieling, 2014). Thus, addressing urban challenges require a broader spatial focus that extends beyond the city limits.

Many have mentioned that urbanisation brings positive and negative benefits to the communities as well as to the country. New developments brought about by urbanisation have important implications for the livelihoods and socioeconomic conditions of local communities (Elhadary et al., 2013). Through good infrastructures and access to basic facilities and amenities, the urban areas have become more productive economically than the rural areas. This implies that the poor performance of the economy is linked to the increase in rural areas. In addition to the economic benefits, urbanisation provides better access to basic 
Narimah S., Mohd Amirul M., Siti Masayu Rosliah A.R., Yasin E., \& Norzailawati M. N.

Urbanisation Beyond Its Core Boundary and Its Impact on the Communities in George Town Conurbation, Malaysia

facilities such as health, education, water, and electricity. Urbanisation brings more employment opportunities and offers modern lifestyles in the city $(\mathrm{Su}$, Jiang, Zhang, \& Zhang, 2011) and these facilities are positively correlated with human development. For example, major cities become megacities which can handle major international commercial activities (Cavallier, 1996).

Some empirical evidence has shown that there is a link between city size and poverty eradication. According to Knieling (2014), poverty is more widespread and deeper in very small and small towns than in large or very large cities. For example, poverty in metropolitan cities, in particular, are considerably lower than poverty in other urban areas. This claim is supported by UN-Habitat (2016), which stated that cities have higher productivity, stronger economies and more employment opportunities, and the rapid pace of urbanisation has helped millions to escape from extreme poverty.

However, the abovementioned positive views are debatable and do not always have a linear relationship. Urban conurbations pose a challenge to urban planners and decision makers. Malaysia, for example, is classified as among the most urbanized countries with the urban population rising rapidly, especially in major urban centres of Kuala Lumpur, Johor Bahru and Georg Town. This phenomenon has created major challenges to local authority in handling the increasing number of urban population and in providing access to better services. Regardless of the emphasis on whether urbanisation has positive or negative outcomes, empirical research on urban conurbation is still lacking (Samat et al., 2014).

This paper aims to identify and map out urban expansion in the George Town Conurbation, and evaluate its impact on the communities living in this conurbation. In addition, the paper seeks to understand the impacts of urbanisation from the perspectives of the local communities.

\section{BACKGROUND OF THE STUDY}

Penang, along with Kuala Lumpur, Selangor and Johor, has experienced rapid urbanisation since the 1970s, mostly due to industrial activities (Ghazali, 1999). Penang has contributed 6.6\% of Malaysia's Gross Domestic Product (GDP) in 2015 after Selangor (22.6\%), Kuala Lumpur (15.1\%), Sarawak (10.0\%), Johor (9.3\%) and Sabah (6.6\%) (Department of Statistics Malaysia, 2016). Since the 1970s, Penang has focused on industrial and commercial activities to boost its economy and has invested in improving public infrastructures that can attract multinational corporations and international investors (Samat et al., 2014).

Industrialisation and commercial activities have provided wide employment opportunities that consequently led to the migration of the rural population into the Penang state (Ghazali, 1999). Thus, the demand for land for housing and related activities has increased. Furthermore, Penang has the highest urban population density in Malaysia with 4,800 people per square kilometre 
PLANNING MALAYSIA

Journal of the Malaysia Institute of Planners (2019)

(Demographia World Urban Areas, 2017). Urbanisation in Penang has spilled over to its neighbouring regions (Hasni \& Samat, 2015). Good road network, cheap land prices, peaceful environment and less densely populated areas are among the major factors that have attracted new developments, especially housing areas to the neighbouring regions. In addition, the North-South Highway and Butterworth-Kulim Highway connecting Penang and its neighbouring regions have attracted people to stay in the neighbouring regions and commute to work daily. New constructions of residential and business units and administrative complexes foster the economy in the regions. This development, however, brought some consequences to the community living in the surrounding regions (Su et al., 2011). The urbanisation experienced by George Town and its neighbouring regions, has attracted this paper to examine the expansion of George Town, besides the perception of its community on the development and the consequences that arose in their surroundings.

\section{MATERIALS AND METHODS}

\section{The Study Area}

George Town Conurbation is located in the north of Peninsular Malaysia with Pulau Pinang (George Town and Butterworth) as the centre. The Northern Region urban conurbation stretches from Sungai Petani in the north to Kulim in the east and Sg. Bakap in the south (Figure 1). The Census 2000 statistics estimated that the Northern Region urban conurbation has a population of at least 1.2 million or $23 \%$ of the region's total population (PlanMalaysia, 2016).

\section{Spatial Data}

Spatial data are mainly used to identify areas undergoing high development pressure. This study used satellite images of the year 2002, 2006, 2010 from Landsat 7, and year 2014 from Landsat 8, available from the United States Geological Survey (USGS) website to locate urban expansion within the study area (USGS, 2015). These images were processed using Erdas Imagine 2014 software and referenced on UTM-47N with Upper Left, $X=630210$, Lower Right, $\mathrm{X}=706680$, Upper Left, $\mathrm{Y}=648900$, Lower Right, $\mathrm{Y}=550860$ and have a spatial resolution of 30 meters $\mathrm{x} 30$ meters. The images were then classified using maximum likelihood supervised classification into four major land covers, namely Agriculture, Forest, Urban and Water Body. The overall accuracy of the classified images was $80 \%$. These classified images were exported into ArcGIS 10.1 shapefile and used to map land cover and identify urban development pressure. 
Narimah S., Mohd Amirul M., Siti Masayu Rosliah A.R., Yasin E., \& Norzailawati M. N.

Urbanisation Beyond Its Core Boundary and Its Impact on the Communities in George Town Conurbation, Malaysia

\section{Household Survey}

The main objective of this study is to investigate how local communities perceive urban development in Malaysia. To achieve this objective, the study employed a mixed methods approach (qualitative and quantitative approaches) to capture the communities' views towards urban conurbation. A sample of 12 respondents living in George Town Conurbation were identified for in-depth interview to express their responses to issues and impact of the development on their livelihoods.

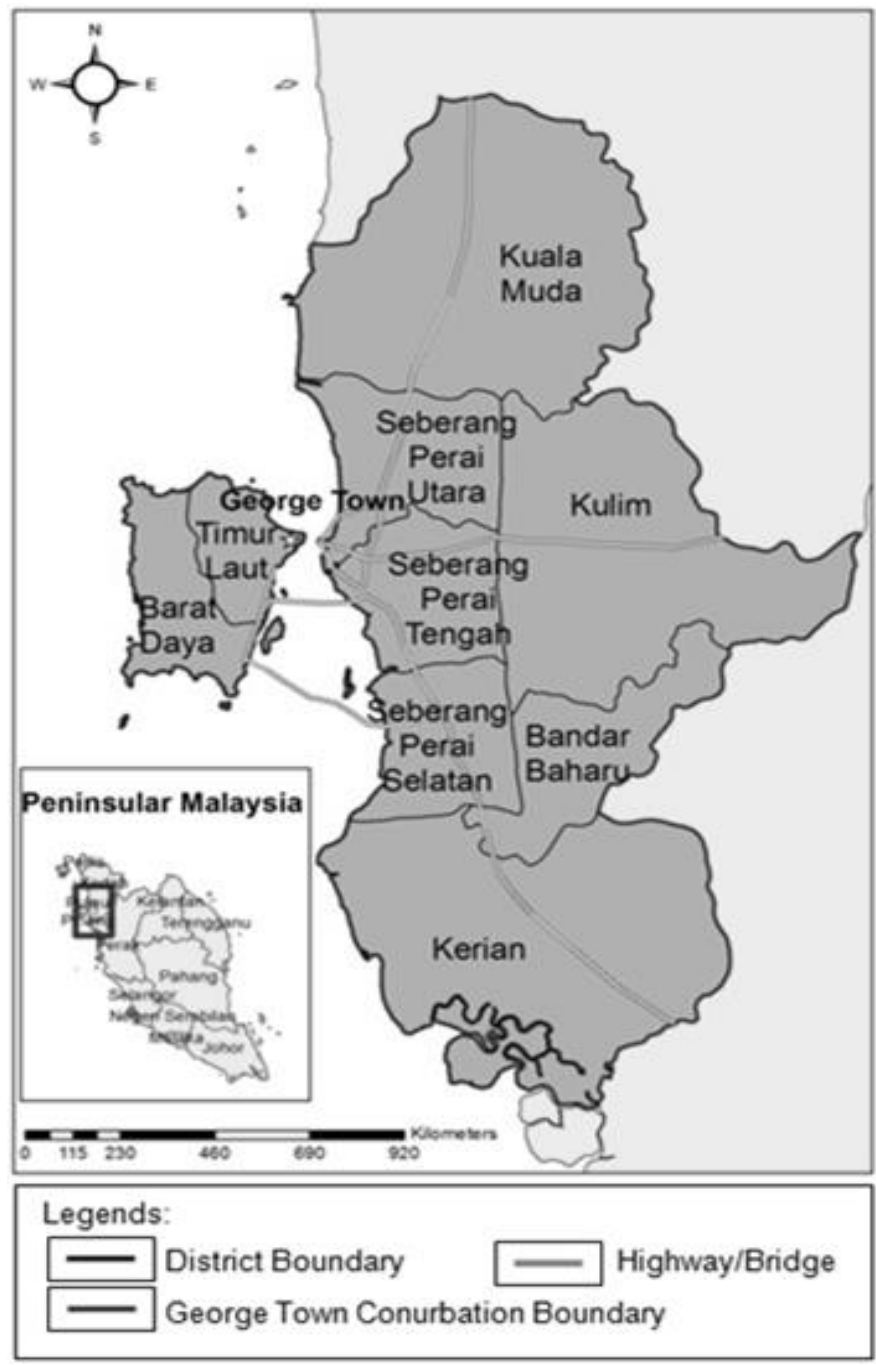

Figure 1 George Town Conurbation 
PLANNING MALAYSIA

Journal of the Malaysia Institute of Planners (2019)

A household survey involving 550 respondents clustered within three districts were selected using convenience sampling. A questionnaire was conducted on the sample to evaluate the perspective and impacts of urban development on the local communities. Three neighbouring regions were identified as the study areas, namely Kerian (in Perak), Kuala Muda (in Kedah), and Bayan Lepas in Penang. Bayan Lepas was selected to evaluate the perspective of Penang's community about the Penang, and to assess if there are any differences in views among the communities. The study was designed to understand the views and situations experienced by the local communities. Of the 550 respondents, 208 or $41.6 \%$ were from Kerian, 214 or $42.8 \%$ from Kuala Muda and 128 or $25.6 \%$ from Bayan Lepas. In addition, other key relevant data such as meetings with city planners from Kerian (Kerian District Council) and Kuala Muda (Majlis Perbandaran Sungai Petani) were also used to examine the preparations and actions taken by local authorities to manage the rapid development of the study areas.

\section{LAND COVER CHANGES 2002 - 2016}

Analysis on the time series satellite images (Table 1) showed that land cover in the study areas has experienced significant changes during the observed period (Figure 2). Built-up area has increased from $1,398.12 \mathrm{~km}^{2}$ to $1,704.47 \mathrm{~km}^{2}$,a total increase of more than $300 \mathrm{~km}^{2}$ during observed period. Similarly, agriculture area has increased of more than $1500 \mathrm{~km}^{2}$, while forest area experienced a reduction of more than $1700 \mathrm{~km}^{2}$. Furthermore, land cover changes indicated that urban areas and agricultural are growing at the expanse of forested area. As stated by FAO (2016), agriculture is still the major driver of deforestation globally. Based on this observation, this study identified areas undergoing urban development pressure namely south of Seberang Perai Selatan and North of Seberang Perai Utara. Kerian District received spill-over demand for housing and other related services from rapid urbanisation in the south of Seberang Perai Selatan. For example, the development of Penang second bridge connecting Batu Kawan in Seberang Perai Selatan and Batu Maung in Bayan Lepas has spurred urban development around these regions ("Penang second bridge to spur", 2012). Although Bayan Lepas has experienced urban development pressure since 1970s, it has become more intense as more infrastructure and industrial sites being developed (Samat et al., 2014). Similarly, more development moved towards Kuala Muda district due to spill over development of Sungai Petani area. 
Narimah S., Mohd Amirul M., Siti Masayu Rosliah A.R., Yasin E., \& Norzailawati M. N.

Urbanisation Beyond Its Core Boundary and Its Impact on the Communities in George Town Conurbation, Malaysia

Table 1 Area of classified land cover between 2002 and 2014

\begin{tabular}{cccc}
\hline Year & Agriculture $\left(\mathrm{km}^{2}\right)$ & Forest $\left(\mathrm{km}^{2}\right)$ & Urban $\left(\mathrm{km}^{2}\right)$ \\
\hline 2002 & $1,266.65$ & $3,006.08$ & $1,398.12$ \\
2006 & $2,354.18$ & $1,889.49$ & $1,504.61$ \\
Change & $+1,087.53$ & $-1,116.59$ & +106.49 \\
\hline 2006 & $2,354.18$ & $1,889.49$ & $1,504.61$ \\
2010 & $2,799.28$ & $1,306.01$ & $1,502.74$ \\
Change & +445.10 & -538.48 & -1.87 \\
\hline 2010 & $2,799.28$ & $1,306.01$ & $1,502.74$ \\
2014 & $2,815.06$ & $1,212.54$ & $1,704.47$ \\
Change & +15.78 & -93.47 & +201.73 \\
\hline Total Change & $+1,548.41$ & $-1,793.54$ & +306.35 \\
\hline
\end{tabular}

Note: Calculation shown in this table was based on calculation from classified satellite images generated by authors.

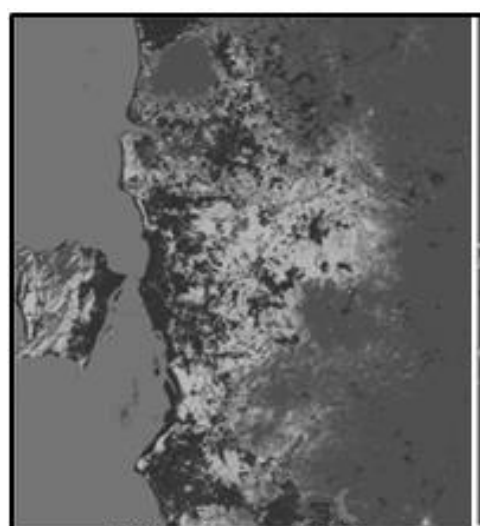

(a) Land cover 2002

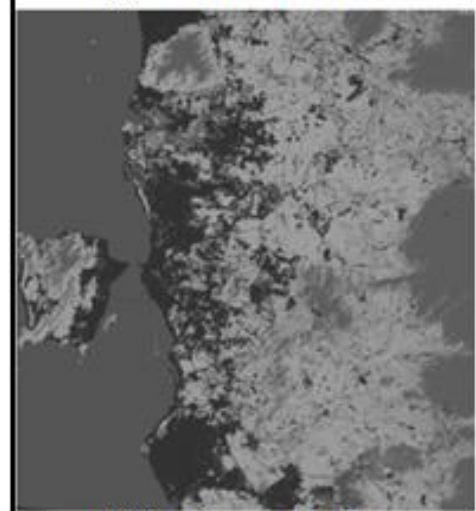

(c) Land cover 2010

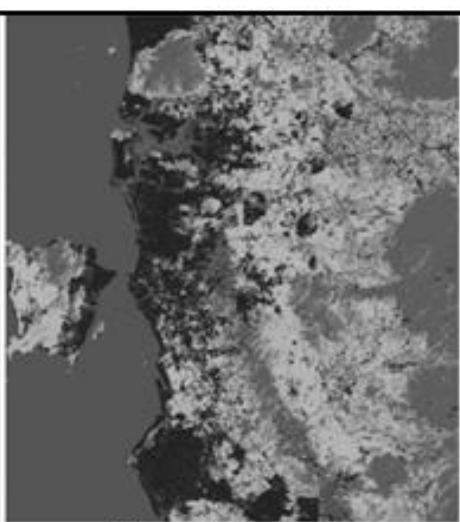

(b) Land cover 2006

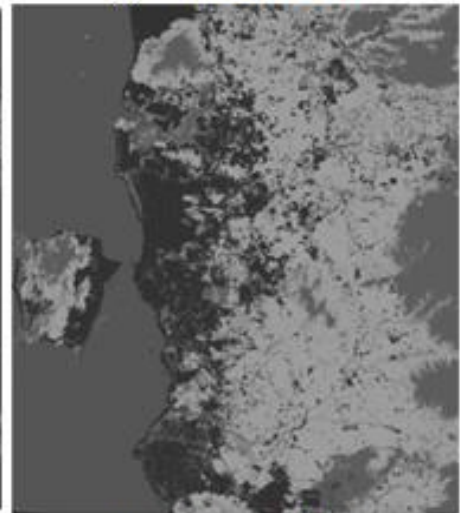

(d) Land cover 2014

Figure 2 Land cover 2002, 2006, 2010 and 2014 produced using maximum likelihood supervised classification method 
PLANNING MALAYSIA

Journal of the Malaysia Institute of Planners (2019)

Table 1 shows that urban development has caused a reduction in forest area by $7.2 \%$ between the year 2010 to 2014. Agricultural area, on the other hand, has increased to 55\%. The reason could probably be that the majority of the local community were still working on their agricultural land, especially in Kerian and Kuala Muda areas. This finding should serve as an alert signal to planners and policymakers that the forest areas have to be managed more efficiently by controlling the spread of newly-developed urban areas. Table 1 shows that urban area has increased by $13.4 \%$ from the year 2010 to 2014 . This is the highest contribution to the total change in the urban area. This could be due to the spill over effect of the development of George Town city that has expanded into the neighbouring regions. The reason could be that the construction of Penang $2^{\text {nd }}$ bridge has spurred urban development particularly housing in the south of Seberang Perai Selatan (Hasni \& Samat, 2015; "Penang second bridge to spur", 2012).

\section{PERCEPTION OF LOCAL COMMUNITIES}

\section{Negative Adaptation: Declining Development}

The study findings indicated that the communities living in Kerian and Kuala Muda (newly developed areas) welcomed urban development around their areas with $49 \%$ and $49.6 \%$ respectively agreeing to the idea. However, only $32.1 \%$ of respondents in Bayan Lepas (developed urban area) agreed with the urbanisation around their area (Table 2). This might be due to the communities in Bayan Lepas have experienced some negative consequences such as congestions and rise of housing rentals and residential land prices in their area (Ghazali, 1999). Besides welcoming development, further analysis indicated that $64.1 \%$ of respondents in Bayan Lepas agreed that migration of newcomers to their area has occurred and $34.4 \%$ agreed that residents have sold their land or house because they were getting high offers from urban developers. On the other hand, Elhadary et al. (2013) found that average agriculture land size has decreased, and farmers were selling their lands and moving out into neighbouring states. To further explore the perception of the community, in-depth interviews was conducted, especially to those living in the Bayan Lepas area since they have seen urban development in the past 40 years. Similar to the findings of the study by Samat et al. (2014), respondents highlighted some negative impacts of the development, namely environmental degradation, traffic congestions and reduction of agriculture land size. 
Narimah S., Mohd Amirul M., Siti Masayu Rosliah A.R., Yasin E., \& Norzailawati M. N.

Urbanisation Beyond Its Core Boundary and Its Impact on the Communities in George Town Conurbation, Malaysia

Table 2 Perception of local community on urbanisation

\begin{tabular}{|c|c|c|c|c|c|c|c|c|}
\hline & & & \multicolumn{5}{|c|}{$\begin{array}{l}\text { Residents welcome urbanisation around their } \\
\text { residence area }\end{array}$} & \multirow{2}{*}{ Total } \\
\hline & & & $\begin{array}{l}\text { Strongly } \\
\text { Disagree }\end{array}$ & Disagree & Neutral & Agree & $\begin{array}{l}\text { Strongly } \\
\text { Agree }\end{array}$ & \\
\hline \multirow{6}{*}{$\begin{array}{l}\text { Study } \\
\text { Area }\end{array}$} & Kerian & Count & 6 & 24 & 76 & 46 & 56 & 208 \\
\hline & & $\%$ & $2.9 \%$ & $11.5 \%$ & $36.5 \%$ & $22.1 \%$ & $26.9 \%$ & $100.0 \%$ \\
\hline & Kuala & Count & 9 & 16 & 83 & 53 & 53 & 214 \\
\hline & Muda & $\%$ & $4.2 \%$ & $7.5 \%$ & $38.8 \%$ & $24.8 \%$ & $24.8 \%$ & $100.0 \%$ \\
\hline & Bayan & Count & 12 & 31 & 44 & 24 & 17 & 128 \\
\hline & Lepas & $\%$ & $9.4 \%$ & $24.2 \%$ & $34.4 \%$ & $18.8 \%$ & $13.3 \%$ & $100.0 \%$ \\
\hline \multirow{2}{*}{ Total } & & Count & 27 & 71 & 203 & 123 & 126 & 550 \\
\hline & & $\%$ & $4.9 \%$ & $12.9 \%$ & $36.9 \%$ & $22.4 \%$ & $22.9 \%$ & $100.0 \%$ \\
\hline
\end{tabular}

The in-depth survey results showed that respondents living in all the three study areas mentioned environmental degradation as one of the main issues. In an in-depth interview in Bayan Lepas, one of the respondents mentioned,

..... the dust and road construction work were too bad, with trucks' noise and heavy traffic. It occurred over a long period of time. The development project was not completed within the prescribed time. (Respondent 1, Male, 60 years old, pensioner).

The community in Bayan Lepas also thought that the development near their residential area has caused housing price to increase. In other words, development has no direct benefit to the local communities. According to one of the respondents,

The housing projects developed are unaffordable to the locals. Mostly they are owned by Singaporeans and Chinese. Development pressure caused local residents to sell their land, but the compensation paid was quite low. (Respondent 2, Male, 47 years old, factory worker).

The development in Bayan Lepas also has negative impacts on students and parents in nearby schools. This was attributed to the development of road widening projects that caused disruptions to some schools in the district. The study found that some schools in the area have been deprived of their fields for their sports activities. This situation gave a negative impact on the development of sports among students. A respondent said,

The road widening project disrupted the school area. The school was affected and causing the site for school to become narrower and no field facility. It caused heavy congestion daily when school start and return time. (Respondent 3, male, 33 years old, public service). 
PLANNING MALAYSIA

Journal of the Malaysia Institute of Planners (2019)

The in-depth interviews also revealed that the community in Bayan Lepas is less likely to welcome development projects around their residential area. The reason is that they considered development as having a negative impact on the local community, but not to outsiders. Only one of the respondents considered that development in residential areas had a positive impact on those living outside the Bayan Lepas area. The respondent said,

Development projects such as road widening, and second bridge are good. But housing and hotel projects do not benefit the locals. Houses are very expensive and it affected us as more people who moved here. (Respondent 4, Female, 39 years old, factory worker).

Overall findings indicated that the development in the Bayan Lepas area brought more negative than positive impacts on the local community. Similarly, the study by Ghazali (1999) and Samat et al. (2014) in Penang State also indicated that respondents experienced negative impacts from urban development. For example, respondents were selling their agriculture land and moving to neighbouring states due to the high land and housing prices, besides avoiding congestion. Although development brought environmental problems, congestion and high land price, few respondents have claimed that the development also had a positive impact on the community. The positive effects identified are discussed in the following section.

\section{Positive Adaptation: Accepting Development}

Even though most respondents felt that development had negative impacts on the local community, there are also some positive impacts from development. Urban development has brought positive impacts to the economy in terms generating more job opportunities, enhanced transportation and communication systems, and improved public amenities, and the living standards of the community. As one of the respondents said,

Housing projects will increase the population. They will bring more business to local food traders. They can create more job opportunities and will increase the income among locals. (Respondent 5, Female, 46 years old, public service).

The findings are in line with the studies by Elhadary et al. (2013) and Samat et al. (2014), that showed that residential development has caused middleincome residents to move into the peri-urban areas and has brought new job opportunities such as child care, tailoring services and other businesses to the region. The findings also showed that development and urbanisation has brought positive impacts to the local communities by bringing in more job opportunities in the non-agricultural sector, enabling the locals to earn better incomes (Ghazali, 1999). One of the respondents said, 
Narimah S., Mohd Amirul M., Siti Masayu Rosliah A.R., Yasin E., \& Norzailawati M. N.

Urbanisation Beyond Its Core Boundary and Its Impact on the Communities in George Town Conurbation, Malaysia

.... since the new road was constructed, access to our business has increased. It also reduced traffic congestion, increased tourist arrivals, and provided a greater market for local business. (Respondent 6, Female, 21 years old, factory worker).

This study found that most of the respondents in Kuala Muda and Kerian (less developed areas compared with Bayan Lepas) welcomed new development into their areas. Ghazali (1999) found that women were able to earn income as more middle-class workers moved to their neighbourhood. This has allowed the local communities to provide childcare services, tailoring services and hawking food by the roadside. The study by Elhadary et al. (2013) also emphasised on the positive impacts that development has brought a market to the people living within new residential areas being developed at the urban fringe. Analysis of the study results shows that; well planned development is essential to ensure that development brings more positive impact not only to the country but also to the communities living within the areas.

\section{CONCLUSION}

As a conclusion, this study finds that the communities in Kerian and Kuala Muda were quite positive with the spillover effects of rapid development from Penang when compared with the community in Bayan Lepas. This study has shown that the physical development of towns within George Town Conurbation has spilled over to the neighbouring regions, affecting the communities. Therefore, a more effective policy response to address the circumstances for Kerian and Kuala Muda should be adopted such as an integrated policy approach to be implemented by the City Council of Penang Island and Seberang Perai Municipal Council to manage the rapid urban development. This finding should be further explored with respect to policy formulation such that urbanisation can be planned and the well-being of communities are safeguarded. More important is that conurbation is essential for the economic growth of developed and developing countries.

\section{ACKNOWLEDGMENT}

This research was funded by the Fundamental Research Grant Scheme, Ministry of Higher Education Malaysia, grant number [203/PHUMANITI/6711472] and Universiti Sains Malaysia's Research University Team Grant [1001/PHUMANITI/856002]. Authors also acknowledged funding support for Siti Masayu Rosliah Abdul Rashid through Universiti Sains Malaysia postdoctoral fellowship program. 


\section{REFERENCES}

Cavallier, G. (1996). Urbanization in developing countries. Urbanisme, 4-11.

Demographia World Urban Areas (2017). Built up urban areas or world agglomerations: 13th annual edition. Retrieved Jan 1, 2018 from www.demographia.com/dbworldua.pdf

FAO (2016). State of the world's forests 2016. Rome: (n.p.)

Department of Statistics Malaysia. (2016). Malaysia's GDP by states, 2010-2015, Kuala Lumpur, released on 30 September 2016.

Elhadary, Y., Samat, N., \& Franklin, O.O. (2013). Development at the peri-urban area and its impact on agricultural activities: An example from the Seberang Perai Region, Penang State, Malaysia. Agroecology and Sustainable Food Systems, 37(7), 834-856.

Ghazali, S. (1999). Socio-economic changes in the peri urban villages in Penang, Malaysia (Doctorate dissertation). University of Leeds, Leeds, UK.

Hasni, R., \& Samat, N. (2015). Predicting Seberang Perai housing land pattern in 2017. In Proceedings of International Conference on Development and Socio Spatial Inequalities 2015, 216-223.

Jedwab, R., \& Vollrath, D. (2015). Urbanization without growth in historical perspective. Explorations in Economic History, 58, 1-21.

Knieling, J. (2014). Metropolitan regions definitions, typologies and recommendations for development cooperation, Discussion Paper Series.

McGee, T. (2009). The spatiality of urbanization: the policy challenges of mega-urban and Desakota Regions of Southeast Asia. UNU-IAS Working paper no. 161. Retrieved from www.as.unu.edu/resource_centre/161\%20Terry\%20McGee.pdf

PlanMalaysia (2016) Dasar Perbandaran Negara 2. Kuala Lumpur: Author.

Samat, N., Ghazali, S., Hasni, R., \& Elhadary, Y. (2014). Urban expansion and its impact on local communities: A case study of Seberang Perai, Penang Malaysia. Pertanika. Social Science \& Humanities, 22(2), 349-367.

Su, S., Jiang, Z., Zhang, Q., \& Zhang, Y. (2011). Transformation of agricultural landscapes under rapid urbanization: A threat to sustainability in Hang-Jia-Hu region, China. Applied Geography, 31, 439-449.

Penang second bridge to spur state's economic development (2012). Retrieved from https://www.thestar.com.my/news/nation/2012/07/05/penang-second-bridgeto-spur-states economic-development/

United Nations (2014). World urbanization prospects: The 2014 revision. Retrieved from http://esa.un.org/unpd/wup/

UN-Habitat. (2016). World cities report 2016. Urbanization and development: Emerging futures. Retrieved from http://wcr.unhabitat.org/wp-content/ uploads/2017/02/WCR-2016

United States Geological Survey [USGS] (2015). Earth explorer: Maps, imagery and publications. Retrieved from http://earthexplorer.usgs.gov/ 